\title{
INTRODUCING WITH MICROBES: FROM WITNESSING TO WITHNESSING
}

\section{The Kilpisjärvi Collective}

IN JANUARY 2020, 15 SOCIAL SCIENTISTS AND THREE ARTISTS MET AT A biological research station in Kilpisjärvi, Lapland, northern Finland. We spent a week rigorously discussing a set of chapter drafts for this book and experimenting with possibilities of working and writing with microbes. The remote location by a frozen lake, surrounded by snow-covered hills with mythical relevance to Sámi culture, the magical polar nights, the scarcity of daylight and the warmth of the fireplace all contributed to an organic and fluid cohabitation and collaboration. Intensive reading and commenting were complemented by material, corporeal engagements with microbial worlds. Engaging with microbes was not only - and cannot only be - textual. Through movement explorations with slime mould and vagus nerve yoga, culturing bacteria in bread and ginger beer and making cheese, and an artistic performance 'Labracadabra' that included three bioartists collecting samples from the bodies of the participants, then culturing them in the research station's laboratory and giving tarot-style predictions from them, we drew our human selves into new connections with various kinds of microbes in ways that aimed to increase our awareness of the microbes in and around us, and possibly change our theorisation of them.

The tone of the week was set during the first night, with a slime mould exercise organised by Vishnu Vardhani, one of the bioartists attending the workshop. During a processual movement and immersion exercise, we were asked to collectively move as one, remaining aware of our environment and of our own and others' boundaries, despite having our eyes closed. A slime mould is a community of single-cell organisms with many nuclei fused together that 
act as one collective entity with no central operating system (Barnett 2015). The exercise required a great deal of mutual attuning, which was also central to the work during the following days and the organising and writing of this introduction together. We did not know then how much we would soon long for the presence of strangers.

It would be a mistake to use slime mould as a new metaphor for the social. While the objective of our time in Kilpisjärvi was to play with microbes, there was also a need to dislodge notions of authority, authorship and agency of the human. Epistemic experimentation was required to add further layers to knowing microbes at both an individual and a collective level. We wrote this introduction together and author it as the 'Kilpisjärvi Collective'. In doing so, we are crossing the many boundaries of authorship upheld by the writing norms of each of our disciplines; and we are developing new slime mould-inspired knowledge production practices based on what 'we' learned from engaging with microbial life forms. In Kilpisjärvi, the chapters were discussed by the group. This discussion contributed to the individual papers but also to the joint process of carving out a new niche for the social study of microbes. As such, the whole of this book is bigger than the sum of its parts.

We do not consider attuning to microbes to be the next important turn in the social studies of science (after the gene, stem cell, etc.). We agree with Stefan Helmreich (2003) that 'microbes are good to think with' - but they are also so much more than that. In this volume, we circle in on the 'with' to describe multiple microbial relationships and networks as they emerge and shift, and how various relations change their contexts in so doing. Accompanying, following, embodying these entanglements is what we decided to call 'withnessing'.

\section{PATHOGENS AND PANDEMICS}

Upon returning home, we heard the first reports of a novel respiratory disease making people ill in the Chinese city of Wuhan. This book was written during the lockdowns of 2020, at a time when the world was struggling with a pandemic caused by SARS-CoV-2. The disease itself, called Covid-19, was regularly 
described in the media in military terms; the virus was referred to as an enemy, and societies were said to be at war with it. Such a discourse represents a view of microbes that has dominated public health and biomedicine, and that has had strong resonance in public lives (Brives 2020). The germ theory sees microbes as causing diseases, and developments in public health during the twentieth century have enforced practices that define microbes as a quintessential enemy of health due to their detrimental effects on human and animal lives (Sariola and Gilbert 2020).

This paradigm remains strong throughout the world, as evidenced by the way it shapes regulatory tools for the prevention of epidemics, hygiene and food safety. In her analysis of raw milk cheesemakers in the US, Heather Paxson coined the term microbiopolitics to describe the governance of microbes. Paxson takes a cue from Foucault's (2008) notion of biopolitics, which refers to the ways in which power and biological life are intertwined in order to organise life and populations. Paxson (2008: 17) defines microbiopolitics as 'the creation of categories of microscopic biological agents; the anthropocentric evaluation of such agents; and the elaboration of appropriate human behaviours vis-a-vis microorganisms engaged in infection, inoculation, and digestion'. Biopolitics was formulated at a time when genetic medicine did not exist, and the main cause of death was infectious disease. Thus, it is not surprising that, though never explicitly articulated as such by Foucault (or Paxson), a central component of biopolitics - the production of healthy populations through public health measures - was the control of microbes.

Microbiopolitics, therefore, is not limited to artisanal cheesemakers, but can be extrapolated to the ubiquity with which the governance of microbes has penetrated various domains of modern societies. From food hygiene (Nading 2017) to the organisation of human and animal health care (Hinchliffe et al. 2016; Chan et al. 2020; Keck 2015; Sanford, Polzer, and McDonough 2016), pandemic preparedness (Lynteris and Poleykett 2018; Caduff 2012) and even architecture (Brown et al. 2019), microbes have been predominantly framed as contagious pathogens in need of control. Such an approach, termed an 'antibiotic approach to life' by Jamie Lorimer (2020), which aims to control human-microbe boundaries with antibiotics, the quintessential modern tools for 
governing microbes, has had dramatic outcomes for human and animal health, having led to the rise of antimicrobial resistance (AMR) (Kirchhelle 2020).

Hannah Landecker (2016) argues that antimicrobial resistance is a natural quality of microbes, but the use of antibiotics has accelerated the evolution of resistance, changing the biological qualities of microbes. Steve Hinchcliffe (2021) describes this as 'a play of forces' whereby socio-political conditions generate material (microbial) push-back. Social analyses of AMR have, for example, pointed to the ways in which antibiotics are a 'quick fix' (Denyer Willis and Chandler 2019) to control and guard against infection in the absence of health care. This applies to poorly equipped health care systems in low- and middle-income countries as well as conditions of neoliberal pharmaceuticalised healthcare characterised by individual responsibility via the use of antibiotics.

Attempts to control the circulation of microbes capable of rapid transnational reach have led to a proliferation of pandemic thinking at the global level: long before the international spread of SARS-CoV-2, in public health discourse, the next outbreak was always just around the corner (Caduff 2015; Lakoff and Collier 2008; Wald 2008). National and international infrastructures have been set up to prevent the spread of microbes, and work by scholars in sociology and international relations has drawn parallels between how nation states manage their borders against outsiders and how the body is seen to defend itself from pathogens (Brown 2019; Fishel 2017; Martin 1990). The 2000s saw an expansion in literature on preparedness against pandemics and bioterrorism that described regulatory measures such as surveillance, quarantine, separating high-risk individuals, monitoring and tracing, and rolling out global health preparedness policies (Wolf 2017; Keck and Lachenal 2019; Lakoff 2017; Cañada 2019; Caduff 2019).

While the 2020 Covid-19 pandemic reinforced these themes, the damage to health and economies is masking a more dynamic and complex notion of microbes that had been starting to take hold. An alternative definition of humanmicrobial relationships, taking into account the ecological dimension of diseases, has persisted throughout the twentieth century in disciplines such as microbial ecology (Anderson 2004), but in public health it was not until the early 2000s and technical developments in the field of genetic sequencing that significant 
changes were observed, first in the life sciences and biomedical sciences and then in the humanities and social sciences.

\section{SYMBIONTS AND SITUATEDNESS}

The early 2000s saw the development of metagenomics - the study of the genetic content of samples from complex environments that dissolves the boundaries of individual organisms and species, both materially and conceptually. Since then, this discipline has provided growing support for a story in which humans and microbes share common ecologies and maintain constitutive relationships. Work on microbiota thus provides evidence that, among other things, humans depend on microbes from a developmental, immunological, physiological and metabolic point of view (Gilbert, Sapp, and Tauber 2012). The concept of the holobiont, which accounts for this entanglement between a host and its symbionts, is thus being used more and more widely (Bosch and Miller 2016). However, in order to avoid the pre-eminence of one entity (the human) over the others (the microbes), Donna Haraway proposes to renounce the notion of host; for Haraway, a holobiont is an assemblage of symbionts (Haraway 2016). And importantly, for some ecological thinkers, viruses can also make symbiotic relations (Dupré and Guttinger 2016). Pierre-Olivier Méthot and Samuel Alizon (2014) show how pathogenicity should be viewed as a dynamic feature of an interaction between biological entities, rather than as a fixed notion.

By bringing microbes into the focus of what it means to be human, much that may have been taken for granted is brought into question. For example, the role of microbes in the human immune system has led to a reconsideration of the dichotomy between 'self' and 'non-self' that has been central to immunology for decades (Rees 2020; Martin 1990). Instead of seeing the body as a self that protects individuality against outside influence, philosopher of biology Thomas Pradeu points out that 'many foreign entities are tolerated by the body and even become major constituents of the organism, especially bacteria that have symbiotic relationships with it, such as bacteria from the gastrointestinal tract' (Pradeu 2008: 118-9, translation CB). Far from encouraging withdrawal 
into oneself, into genetic essentialism or a fixed conception of the boundaries of what would define us as human beings, biology tells us today that 'foreign' entities - microbes - become crucial constituents of the organism through the immune system. Furthermore, microbes' ability to share genes across species - lateral or horizontal gene transfer - questions the self-evidence of individuality at all scales. What is at stake, however, is not figuring out where the 'real' individual lies but tracing how 'what the individual is' shifts according to what it is asked to do. Social sciences have long argued that persons are distributed, non-essential, fluid and relational, but work on immunity and symbiosis demonstrates the profound implications of a relational conceptualisation for the biological notion of 'self' that Roberto Esposito (2010) and Nik Brown (2019) have argued reorganises relations with others by an emphasis on community rather than immunity.

Considering microbes as relational brings attention to the broader social relations and power structures where they are embedded. It is necessary to address the power relations that frame human-microbial relations and consider the status, legitimacy and capacities for political action of the different actors involved. Although new forms of relationships with microbes seem to be on the rise - characterised by Lorimer (2020) as a probiotic turn, where 'life is being used to manage life' - it is important not to overestimate these relationships, to recognise that they are above all 'humanist', and so to locate them within the structures of human societies. Fermentation practices, attention to our guts, alternative medicines and other 'friendly microbial practices' are not equally distributed across the globe and within societies, and therefore do not have the same meaning for everyone. It is important to recognise the socially situated dimensions of such practices, and how factors such as gender, class, race, age and culture impact, and arise within, our relations with microbes, depending on geographical and historical contexts, existing sanitation infrastructures, lifestyles, access to types of food and health care, and the environments that people live in - dynamics that Amber Benezra (2020) calls intersectional biosociality. The pandemic also cautions us about the location and relationship of the new multispecies practices with microbes in relation to the dominant framework of biosecurity and provides reasons to analyse the possible tensions and challenges 
that practices such as fermentation or alternative sanitation might pose to it. A new focus on microbial scales should not imply disregard of macroscopic structures and social justice.

\section{FROM WITNESSING TO WITHNESSING: A NOTE ON METHOD}

Within growing bodies of work concerned with human-microbe relationalities, both in the life sciences and social sciences, there is little sign of consensus around preferred methods or scales of enquiry. Approaches are numerous, techniques and devices are varied. Microbes, fluid and dynamic, thus remind us of the strength and fragility of knowledge, whether scientific or vernacular. Given the circular and multi-contained character of ecologically situated multispecies relationships, there is a pressing need to develop the tools and vocabulary for the social sciences and humanities to move away from a purely anthropocentric focus. How can we describe, and generatively engage, microbial multispecies relations without dichotomising nature and culture, subject and object, human and other? And how can we describe how humans and microbes compose common worlds together?

The chapters of this book document the entanglement/hybridisation between different forms of knowledge and practices regarding microbes and their circulation within multiple social worlds. They resist the urge to represent and thereby configure the object of knowledge - the microbe - as a stable entity that can be known. The traditions of knowledge practices, where the human involvement with microbes instrumentalises and objectifies the known, and where human intentionality, mastery and control are taken as given goals, are challenged and refused. The knowledge, technologies or devices that are mediating our interactions with microbes can make them either visible or invisible.

While many chapters share overlapping vocabularies, epistemologies and ontologies, these always exist also in relation to varying ways of knowing, making things visible or knowable as an object of care or concern. How things 
are enacted by the various entities engaged in the practice produces multiple versions of materiality ( $\mathrm{Mol} 2002)$. Would we be speaking of 'microbes', even in relational terms, if it were not for the ever-changing microbiological techniques of making-visible, understanding, isolating and quantifying?

With Microbes examines how multiplicities of microbial life are enacted, to develop nuanced and speculative ways of talking about the kind and degree of human involvement with them rather than an assumed neutral observation. This could be described as a move from 'modest witnessing' (Haraway 1997), where the experiment establishes the facts about its target, towards 'withnessing. Haraway draws on the writings of Shapin and Schaffer (1985) about the seventeenth-century scientist Robert Boyle to discuss the kind of modest witnessing accessible only to white, male and middle-class bodies. Only this form of modesty permitted the objective gaze required of witnessing in credible science. In contrast, the modesty of Haraway's feminist mutated Modest Witness - and the notion of withnessing we discuss below - is about knowledge as situated, immersed and partial.

The notion of 'withness', raised by Sally Atkinson (2021) in Kilpisjärvi and discussed collectively during the workshop discussions, is a commentary on the aspired-to neutrality of the modest witness. Withnessing becomes one way to name and bring together the otherwise diverse approaches to knowledge production taken in this volume. The epistemic orientation of withnessing the 'knowing' - is dispersed, and non-human vitality, agency or liveliness is as much an object of curiosity as human engagement (for a similar postulation of withnessing as more-than-human co-existence, see Boscacci 2018). In many chapters of this book, the intentional human engagement with microbial processes is of interest, but it is not the central focus. By drawing on multispecies ethnographies (Kirksey and Helmreich 2010; Tsing 2015; Haraway 2008), we zoom in on 'contact zones where lines separating nature from culture have broken down, where encounters between Homo sapiens and other beings generate mutual ecologies and co-produced niches' (Kirksey and Helmreich 2010: 546). Here, the aim of grasping a confluence of interacting multispecies relations decentres the human, while at the same time recognising the challenges of sidestepping it. 
In contrast to the ocular, cerebral and objectifying gaze of the witness, in withnessing, the relationality in any knowing process is brought to the analytical focal point. Relationality, again, means that knowing is always contingent, emergent, sensory, embodied, social, and animated by multiple, unexpected human, non-human and inhuman agencies. To understand through 'withnessing' is therefore not to claim a panacea or propound a celebratory account of knowing as necessarily possible, unproblematic, reciprocal, nor even arising out of peaceful coexistence. Even the clumsiness of the term on the tongue speaks to the inherent discomforts, the visceral violence, unevenness, and divergences in knowing as withnessing.

In the process of knowing as withnessing, the (infra)structures, knowers, tools or devices for human-microbial engagement become key sites of interest. The focus shifts from the entity to be known to the 'agential cut' (Barad 2007) of knowledge production. In her seminal work on quantum physics, Karen Barad argues that the measurement, technology, technique or surface on which the knowledge is drawn constitutes the phenomenon itself. In With Microbes, the microbe is sensed with widely different tools. Devices are seen as technological mediators that constitute the phenomenon itself; therefore, the site to be studied becomes one of the major choices for the ethnographer. Bruno Latour's (1993) historical work The Pasteurization of France was instructive in showing that a device, or a collection of devices such as the laboratory, never only constitutes the entity but also its governance. In the science and technology studies tradition that this book engages with, attention to disciplines, as well as lay knowledge, leads to a focus on practices and processes rather than outcomes only. Importantly, the chapters counter the impression that it is first and foremost the laboratory where the presence and absence, the visibilisation and invisibilisation of microbes, is enacted. Instead, the chapters offer insights into the various other sites where microbes are co-enacted, or 'withnessed': gardens and farms, kitchens and communities, environments and infrastructures.

Devices and configurations of knowledge, including disciplines, should always be understood as both constructed through relations of power and as the machinery through which power operates (Foucault 1980). The ideal of the 
'knower' as a colonial, masculine, white, phallogocentric subject who controls his object, for example, is in many respects challenged in this volume. However, it is important to acknowledge the ways in which this ideal continues to 'stick' and seduce (Ahmed 2016). Similarly, an account of 'withnessing' microbes could all too readily risk focusing on microbial-human relations without situating these relations within capitalist, patriarchal and white supremacist relations of power - which condition the very possibilities and limits of these relations and how they are valued and known. The context, obligation and cosmopolitical ethos in which these shared practices take place are part of what Isabelle Stengers (2005) has called 'an ecology of practices'. In turn, microbial-human relations are enrolled to reproduce such hierarchies of value, reinforcing which (non-)humans and ways of being (in)human(e) are valued.

The chapters that understand human-microbial relations as configured through relations of power show special interest in how to attend to living materiality and to the question whether the boundary between living and non-living can be maintained as binary opposition. Power operates through these relationships not only in terms of 'interests', understood as 'political', or through discourse alone but also in terms of what forms, infrastructures and understandings of humanity, life and 'vitalness' are sustained, and which are left to die (Sharpe 2016). The chapters recognise that governance is not about power over given individuals or species, but rather about power relations within multispecies or even ecosystem-based assemblages (e.g. Agamben 1998; Povinelli 2016; Weheliye 2014; Mbembe 2019). Of the many interpretations of the meaning of 'critique' in critical analysis, Patricia Hill Collins (2019) reminds us of definitions that are vital and even lifesaving; as in 'critical care'. Critical social scientists interested in microbial sciences end up entangled with their human and non-human collaborators and the devices they operate with and cannot quite afford arrogant sceptical oppositionalism or paranoid distancing (Kirksey 2019; Irni 2017; Sedgwick 2003). Hence, we can but only be 'with microbes', an entanglement that requires situatedness, situating and reflexivity of the methodological, conceptual and ontological positionings of who and what is being drawn together and 'being with'. 


\section{THE MICROBE MULTIPLE: CHAPTER OVERVIEW}

With Microbes aims to refuse the essentialisations that can arise when naming and classifying microbes, as well as the relationships between humans and microbes and among microbes of all kinds (see also Hird 2009). Dualistic analytics are simplifications of historically contingent, geographically and paradigmatically shaped human-microbial relationships. Our ethnographic observations are supported by work from within philosophy, technoscience and feminist anthropology, and the insight that postulating binary oppositions between woman and man, nature and culture, as well as human and more-than-human represent analogous moves that legitimate domination by man, culture and human (Strathern 1980; Haraway 1985; Braidotti 2006).

Nonetheless, while recent contributions to the social studies of microbes have acknowledged the multiplicities of microbes (e.g. Kirksey 2019; Lorimer 2017; Paxson 2012; Helmreich 2009; Jasarevic 2015; Kalin and Gruber 2018), the analyses of many social scientists remain dualistic. Paxson (2008: 17-8) argued that the revival of artisanal cheesemaking in the United States 'provides a window onto social and regulatory negotiations of a hyperhygienic Pasteurian social order (as forwarded by the FDA [Food and Drug Administration]) and a post-Pasteurian microbiopolitics' advocated by raw milk activists. This binary juxtaposition risks a simplifying depiction of the history of microbiology. 'Pasteurian' here might be read as a monolithic ideology concerned with seeing microbes as nothing but pathogenic threats. In a similarly dichotomous vein, Lorimer (2020) postulates a 'probiotic' turn in contrast to an antibiotic way of controlling life, and Paxson and Helmreich (2014) frame the new discourse on microbes using the notions of peril and promise.

With Microbes provides descriptions of the multiplicity, complexity, abundance and dynamism of various relationships between humans and microbes. We have organised the chapters into three sections that each highlight a particular mode of relating with microbes and of withnessing - sensing, regulating and identifying. Although this division is not arbitrary, it nevertheless, like any act of classification, cuts out and makes choices about what is put forward for each chapter. This division does not imply an unequivocal mode of relations 
with microbes but rather reflects the choices of each researcher to work on a given scale, and to emphasise one aspect among others of the interactions and becomings of humans with microbes.

\section{Sensing}

The first chapter section, 'sensing', collects a number of contributions that engage with the complex 'arts of noticing' (Tsing 2017) people employ in order to create products, value and meaning as they work and engage with microbes. In this section, we call attention to the series of situated and multisensory practices within which microbes are known and thus come into being (Law and Mol 2008). The chapters are positioned at the interstices of multispecies ethnography and the anthropology of the senses, and draw from diverse sources of the ethnographic tradition, which could be loosely grouped together as nonrepresentational ethnography. As conceptualised by cultural geographer Phillip Vannini (2015), non-representational ethnography stands for making sense of the world while simultaneously considering the partiality, situatedness, contingency and creativity of that sense-making. Embodied, multi-sensory methods have proved useful for such an understanding and have been explored to sense kitchen microbiomes by Lorimer et al. (2019). As Sarah Pink (2012) summarises it, sensory ethnography attends to the non-verbal, kinetic and sensorial ways in which lived worlds are communicated to others. The sensory ethnography approach thus invites us to pay attention to the interplay of sight, touch, smell, hearing, taste and gestures, and the ways they are linked to skilled practices and the use of the technological mediators, such as microscopes, microphones and genome sequencing, in and through which we make sense of the microbial world. The chapters experiment with diverse ways of knowing, not only within fieldwork but also in performing, articulating and communicating our ethnographic explorations.

In 'The Deplantationocene: Listening to yeasts and rejecting the worldview of the plantation', Denis Chartier discusses the motivations and sensory repertoire of winemakers in France who have chosen to leave behind established protocols 
of conventional viticulture and instead produce 'natural wine', a wine without sulphur, laboratory-grown yeasts or pasteurisation. Through an exploration of the historic connections between winemaking, colonialism and the global plantation system that defines the Plantationocene (Haraway et al. 2016), Denis describes these vintners' counter-practices, embodied and sensorial, as bringing forth a Deplantationocene that subverts the ways in which industrial food production and farming create monocultures in which microbes are detached from their environments and instead involves bringing microbes, plants, geology and climate together. Importantly, listening to the sound of the yeast in the vat emerges as a central form of engagement for the winemakers.

In 'Knowing, living, and being with bokashi', Veera Kinnunen investigates a probiotic practice of fermenting kitchen waste called bokashi composting. Focussing on her autoethnographic sensual engagement with waste, interviews with other composters and online forum contributions, she argues for understanding bokashi as an embodied practice that recognises and nurtures microbial wellbeing and rejects a modern ethics of waste denial that is based on separation and rejection. Once again, smelling and touching emerge as powerful ways of knowing microbes.

In 'Oimroas: Notes on a summer alpine journey', Matthäus Rest takes us on a trip through the mountain summer pastures of the Alps where he visits artisanal cheesemakers who work with raw milk. His essay details two scales of pastoral care: how individual cheesemakers care for their starter cultures and how the state keeps the cheesemakers under surveillance. He accompanies a 'cheese consultant' on a day of dairy visits that show how he, like the cheesemakers, first and foremost relies on his senses when encountering both humans and microbes. Identifying a lack of detailed description of the sensual and physical work of cheesemaking in the anthropological literature, Rest argues for an ethnography of microbiopolitics that renders transparent specific microbes' political interventions.

Johanna Nurmi's chapter 'Building "natural” immunities: Cultivation of human-microbe relations in vaccine-refusing families' explores the ways in which vaccine-hesitant parents sense what they understand to be the effects of microbes in strengthening their children's immunity. The parents' position 
and practices are in opposition to the logics by which mainstream public health programmes offer childhood vaccination. Employing the term 'lay immunology', Johanna describes how parents who are critical of vaccines understand microbes and seek to regulate both their own and their children's relations with microbes in their favour in order to develop immunity 'naturally', without the techno-scientifically constructed and controlled means to build immunity with the aid of vaccines.

\section{Regulating}

The second chapter section is 'regulating.' Building on the governance of humanmicrobe relations, a relationship with microbes - be it antibiotic or probiotic or anything else - always involves some degree or kind of negotiation and navigation, at times more open, at times more restricted, depending on what is seen to be at stake, the underlying logic with which microbes are understood and by whom, and to what ends the regulation is implemented. The theme of regulation not only refers to the scale of governance and policies but to how, at micro and macro levels, microbes are managed at and between levels.

STS scholarship has drawn attention to the ways in which science, technology, law, policies and public participation are co-produced (Jasanoff 2004) and shape material worlds (Faulkner, Lange, and Lawless 2012). International standards regulating food safety are a pertinent example of how the circulation and trade of agricultural products are governed and standardised globally, shaping markets as well as everyday relations with microbes (Winickoff and Bushey 2010). We can already observe new kinds of relationship with microbes that are commodified or marketised: kombucha, raw-milk cheese, sourdough and natural wine are among the many products that have become trendy, their availability in the markets enhanced by intermediary actors trying to create a social demand for these products. Given the reach of international food standards and food hygiene, which act as gatekeepers to market access, it is important to question how socio-economic structures foster the development of and potential for 'alternative' approaches to microbes. Privilege, access and structures also 
shape the ways in which people are able to manage their bodily boundaries in relation to microbes.

At the level of regulating relations with microbes at the boundaries of environments and bodies, Katriina Huttunen, Elina Oinas and Salla Sariola's chapter 'When cultures meet: Microbes, permeable bodies, and the environment' highlights the ways in which people's everyday actions regulate the microbes that they perceive to be in the environment and that could make them sick with touristic diarrhoea, entering them at the boundaries of their bodies. The chapter analyses Finnish people who travel to West Africa as part of an Escherichia coli vaccine study. It shows how tourist-trial participants define microbes in multiple ways. A public health framing of microbes as pathogenic is limited, but a dualistic definition of microbes as either 'good' or 'bad' is also seen to be redundant. Katriina, Elina and Salla show that human-microbial relations would better be described on a spectrum, from antagonistic to one of friendly coexistence.

The chapters by Nicolas Fortané, Marine Legrand and Germain Meulemans, and Jose Cañada show how microbes are regulated by policies across animals, water and faeces by national and global health actors, demonstrating the sociopolitical-technical governmentality of human-microbial contact. Crucially, the chapters highlight, following Barbara Praisack and Ayo Wahlberg, that to understand regulatory frameworks, an analytical focus on policy needs to reach over and beyond policy objectives to look at the 'meanings of social conventions, political, legal, and social histories, as well as other informal practices' (Prainsack and Wahlberg 2013: 336) that shape the policies.

Marine and Germain's chapter 'Bathing in black water? The microbiopolitics of the River Seine's ecological reclamation' describes attempts in Paris to eliminate faecal pollution from the River Seine in order to make it swimmable again. The targets of the regulatory intervention to clear the waters are notably the toilets of people living on boats along the river, which are seen to leak faecal matter, a leak objectified and rendered visible by the monitoring of E. coli bacteria. Based on ethnographic research with boat owners and policy makers, the chapter shows the difficulties of and the resistance to setting up the many infrastructures that would be needed to implement this change. The bathing issue opens the black box of sanitation and the structural limits of a centralised system that considers 
the river as a diluting agent. What is for some potential gold (faeces composted into soil for growing food) is for others matter out of place (polluted water). These discrepancies are embodied in different regulatory apparatuses.

Jose Cañada's chapter 'Scalability and partial connections in tackling antimicrobial resistance in West Africa' also shows how microbial policies are socially and spatially contingent. The chapter aims to go beyond the technical description of antimicrobial resistance regulation, which Jose argues 'tends to give a static image of microbes'. In contrast, by focusing on AMR policy-making attempts in West Africa, Jose identifies a number of discursive and material processes that construct these attempts that show the challenges of scale - the macro level of global policy norms vis-a-vis local attempts to set them up. Evoking a post-scalar view of microbes, the chapter demonstrates that while in the sciences microbes are defined by their small scale, their discursive-material status is constituted across different scales of abstraction and thus cannot be separated from the global policies set in place to regulate them.

Nicholas Fortané's contribution 'Ontologies of resistance: Bacteria surveillance and the co-production of antimicrobial resistance' describes how a regulatory mechanism of microbial surveillance for animal health was set up in France. In contrast to claims that biosecurity programmes were 'a new thing' in the 1990s, the chapter shows how programmes to regulate antimicrobial resistance 'didn't emerge from nowhere'. Based on the history and development of surveillance programmes, Nicholas identifies three ontologies of surveillance, their distinctions depending on the professionals involved, the main modes of practice and how microbes were defined. Over time, these ontologies add richness to the different ways in which microbes have been defined, depending on the processes, methods and societal needs at given points in time, a theme explored in the last section of the book.

\section{Identifying}

The third and final chapter section is 'identifying.' Naming microbes, producing classifications and categories, is at the heart of knowledge production. Although 
the various chapters of this book address this issue to varying degrees, identification or characterisation is sometimes concomitant with the establishment of the relationship itself. In Sorting Things Out, Geoffrey Bowker and Susan Leigh Star remind us of the centrality of classification systems to our understanding of the world. Everything that appears as universal or standard in this world is the result of social, political and organisational negotiations, invisible and integrated into the scientific work of describing nature. 'Purely technical issues like how to name things and how to store data in fact constitute much of human interaction and much of what we come to know as natural' (Bowker and Star 2000: 326). Classifications produce units of time and space, multiple ways of relating.

To the multiple ontologies of microbes should then be added the articulation work of different epistemologies. To be truly committed to this multiplicity when it comes to microbes means 'staying with the trouble' (Haraway 2016) of different, not-fully-commensurable onto-epistemologies jostling alongside each other. These different approaches emerge particularly clearly in attitudes towards the historicity of the microbe category.

Each of the chapters in its own way stirs up relational, ontological questions at the heart of microbial social science - questions concerning, among other things, matters of scale, individuality and classification. Many, if not all, engage the conventions of biological taxonomy to describe and discuss microbial kinds as the dominant and to some degree inevitable way of ordering and thus enacting microbial life. However, these chapters do not take on these taxonomic tools uncritically but acknowledge their situatedness (Haraway 1988), engaging with both what they may illuminate and what they foreclose.

In their chapter written in the form of a Greek tragedy 'Scenes from the many lives of Escherichia coli: A play in three acts', Catherine Will and Mark Erickson return to the very dramaturgy of the relationship linking Escherichia coli to the various humans who have worked on and with it. Drawing on their own experience as well as on a large body of literature, they show how the term 'Escherichia coli' names and identifies organisms and populations that sometimes differ depending on the period or discipline by which they are classified. Who is Escherichia coli, anyway? It is less a question of deciding what the 'real' Escherichia coli would be than of situating relationships, of recognising that what 
makes Escherichia coli at a given moment is the material-semiotic relationship in which it and researchers are engaged.

A. C. Davidson's and Emma Ransom-Jones's contribution 'Micro-geographies of kombucha as methodology: A cross-cultural conversation' shows what happens when a human geographer and a microbiologist work on a common project about kombucha and record their interdisciplinary conversations. What is kombucha, and how is it understood? While Emma's student extracted the DNA of commercial kombucha in her laboratory, A. C. conducted interviews with kombucha producers, and both brewed kombucha at home. Their experimental collaboration cautions against imbuing kombucha with radical political potential: kombuchas become within particular micro-geographical conditions of production.

The constitutive character of the relationship when it comes to naming or identifying microbes is at the heart of Charlotte Brives' chapter 'Pluribiosis and the never-ending microgeohistories'. Starting from the therapeutic use of bacteriophage viruses to treat bacterial infections, Charlotte shows, by describing bacteriophage collection practices, how scientists' assignment of a name to a viral strain actually corresponds to a snapshot, at a given time, of a microgeohistory, of an ever dynamic and fluctuating relationship between bacteriophages and bacteria, and their given environments. For scientists engaged in this task, identification is not conducive, at any point of the process, to essentialisation. Rather, it is a way to engage with pluribiosis, with the recognition of the existence of multiple relational spectrums between entities forever in the process of becoming, constantly shaped and transformed by their interactions with other living things. Pluribiosis then allows us to envisage, with the actors of phage therapy, other ways of treating and practising infectiology.

What would happen if anthropologists themselves were to repopulate the classical theories of anthropology with microbes? What would happen if the accounts left space to name and identify the agencies of microorganisms? This is the question posed by Andrea Butcher in 'Old anthropology's acquaintance with human-microbial encounters: Interpretations and methods'. Starting from the observation that the structuralist ethnographies of Mary Douglas and Louis Dumont, although based mainly on the notions of purity and impurity, leave 
little room for substance and materiality, developing almost exclusively symbolic structural analyses, Andrea proposes to search for and designate hidden microbial transcripts in the available ethnographies. She then proposes reflecting on the methodological consequences of the recognition of the place and the naming of microbes in ethnographic narratives.

Engaging with human-microbe relations defies essentialisations in these relationships. Instead, microbes in this volume are multiple, abundant and dynamic, and human-microbial relationships are equally complex. Supported by work from colleagues in technoscience, philosophy and feminist anthropology, the chapters in this book introduce new concepts and methods to understand human-microbial relations and contribute to a transformation of social theory in the process.

\section{CONTRIBUTORS}

Atkinson, Sally

Brives, Charlotte

Biederman, Sabine

Cañada, Jose

Chartier, Denis

Davidson, A.C.

Evans, Joshua

Fortané, Nicolas

Kinnunen, Veera

Legrand, Marine

Oinas, Elina

Rest, Matthäus

Sariola, Salla

Thompson, Andie

Will, Catherine 


\section{REFERENCES}

Agamben, G., Homo Sacer: Sovereign Power and Bare Life (Stanford: Stanford University Press, 1998).

Ahmed, S., Living a Feminist Life (Durham, NC: Duke University Press, 2016).

Anderson, W., 'Natural Histories of Infectious Disease: Ecological Vision in TwentiethCentury Biomedical Science', Osiris, 19 (2004), 39-61.

Barad, K., Meeting the Universe Halfway: Quantum Physics and the Entanglement of Matter and Meaning (Durham, NC: Duke University Press, 2007).

Barnett, H., 'Being Slime Mould', <https://heatherbarnett.co.uk/work/being-slimemould/> [accessed 12 December 2020].

Benezra, A., 'Race in the Microbiome', Science, Technology \& Human Values, 45.5 (2020), 877-902.

Boscacci, L., 'Wit(h)nessing', Environmental Humanities, 10.1 (2018), 343-7.

Bosch, T., and D. Miller, The Holobiont Imperative: Perspectives from Early Emerging Animals (Vienna: Springer, 2016).

Bowker, G., and S. L. Star, Sorting Things Out: Classification and Its Consequences (Cambridge, MA and London: MIT Press, 2000).

Braidotti, R., 'Posthuman, All Too Human: Towards a New Process Ontology', Theory, Culture \& Society, 23 (2006), 197-208.

Brives, C., 'The Politics of Amphibiosis: The War against Viruses Will Not Take Place', <http://somatosphere.net/2020/the-politics-of-amphibiosis.html/> [accessed 12 December 2020].

Brown, N., Immunitary Life: A Biopolitics of Immunity (London: Palgrave Macmillan, 2019).

Brown, N., and others, 'Pathways, Practices and Architectures: Containing Antimicrobial Resistance in the Cystic Fibrosis Clinic', Health, 25.2 (2021), 196-213.

Caduff, C., 'Great Anticipations', in A. Kelly, F. Keck, and C. Lynteris, eds, The Anthropology of Epidemics (New York: Routledge, 2019), pp. 43-58.

The Pandemic Perhaps: Dramatic Events in a Public Culture of Danger (Berkeley: University of California Press, 2015).

'The Semiotics of Security: Infectious Disease Research and the Biopolitics of Informational Bodies in the United States', Cultural Anthropology: Journal of the Society for Cultural Anthropology, 27 (2012), 333-57.

Cañada, J., 'Hybrid Threats and Preparedness Strategies: The Reconceptualization of Biological Threats and Boundaries in Global Health Emergencies', Sociological Research Online, 24 (2019), 93-110.

Chan, K., and others, 'Diagnostics and the Challenge of Antimicrobial Resistance: A Survey of UK Livestock Veterinarians' Perceptions and Practices', The Veterinary Record, 187.12 (2020), e125-e125.

Clever, I., and W. Ruberg, 'Beyond Cultural History? The Material Turn, Praxiography, and Body History', Humanities Report, 3 (2014), 546-66. 
Collins, P., Intersectionality as Critical Social Theory (Durham, NC: Duke University Press, 2019).

Denyer Willis, L., and C. Chandler, 'Quick Fix for Care, Productivity, Hygiene and Inequality: Reframing the Entrenched Problem of Antibiotic Overuse', BMJ Global Health, 4 (2019), e001590.

Dupré, J., and S. Guttinger, 'Viruses as Living Processes', Studies in History and Philosophy of Biological and Biomedical Sciences, 59 (2016), 109-16.

Faulkner, A., B. Lange, and C. Lawless, 'Introduction: Material Worlds: Intersections of Law, Science, Technology, and Society', Journal of Law and Society, 39 (2012), 1-19.

Fishel, S., The Microbial State: Global Thriving and the Body Politic (Minneapolis: University of Minnesota Press, 2017).

Foucault, M., The Birth of Biopolitics: Lectures at the Collège de France 1978-79 (Basingstoke and New York: Palgrave Macmillan, 2008).

The History of Sexuality, Volume I: An Introduction (New York: Vintage Books, 1980).

Gilbert, S., J. Sapp, and A. Tauber, 'A Symbiotic View of Life: We Have Never Been Individuals', The Quarterly Review of Biology, 87 (2012), 325-41.

Haraway, D., 'A Manifesto for Cyborgs: Science, Technology, and Socialist Feminism in the 1980s', Socialist Review, 80 (1985), 65-108.

-Modest-Witness@Second-Millennium.FemaleMan (R)-Meets-OncoMouse ${ }^{\mathrm{Tw}}$ :Feminism and Technoscience (New York: Routledge, 1997).

— 'Situated Knowledges: The Science Question in Feminism and the Privilege of Partial Perspective', Feminist Studies, 14.3 (1988), 575-99.

- Staying with the Trouble: Making Kin in the Chthulucene (Durham, NC: Duke University Press, 2016).

Haraway, D., and others, 'Anthropologists Are Talking - About the Anthropocene', Ethnos, 81 (2016), 535-64.

Helmreich, S., 'Trees and Seas of Information: Alien Kinship and the Biopolitics of Gene Transfer in Marine Biology and Biotechnology', American Ethnologist, 30 (2003), 340-58.

- Alien Oceans: Anthropological Voyages in Microbial Seas (Berkeley: University of California Press, 2009).

Hinchliffe, S., and others, Pathological Lives: Disease, Space and Biopolitics (Malden and Oxford: Wiley Blackwell, 2016).

Hird, M., The Origins of Sociable Life: Evolution after Science Studies (London: Palgrave Macmillan, 2009).

Irni, K. S., 'On the Materialization of Hormone Treatment Risks: A Trans/Feminist Approach', Body \& Society, 23 (2017), 106-31.

Jasarevic, L., 'The Thing in a Jar: Mushrooms and Ontological Speculations in PostYugoslavia', Cultural Anthropology, 30.1 (2015), 36-64.

Kalin, J., and D. Gruber, 'Gut Rhetorics: Toward Experiments in Living with Microbiota', Rhetoric of Health \& Medicine, 1.3 (2018), 269-95. 
Keck, F., 'Liberating Sick Birds: Poststructuralist Perspectives on the Biopolitics of Avian Influenza', Cultural Anthropology, 30 (2015), 224-35.

Keck, F., and G. Lachenal, 'Simulations of Epidemics: Techniques of Global Health and Neo-Liberal Government', in A. Kelly, F. Keck, and C. Lynteris, eds, The Anthropology of Epidemics (New York: Routledge, 2019), pp. 25-42.

Kirchhelle, C., Pyrrhic Progress: The History of Antibiotics in Anglo-American Food Production (New Brunswick: Rutgers University Press, 2020).

Kirksey, E., 'Queer Love, Gender Bending Bacteria, and Life after the Anthropocene', Theory, Culture \& Society, 36 (2019), 197-219.

Kirksey, E., and S. Helmreich, 'The Emergence of Multispecies Ethnography', Cultural Anthropology, 25 (2010), 545-76.

Lakoff, A., Unprepared: Global Health in a Time of Emergency (Berkeley: University of California Press, 2017).

Lakoff, A., and S. Collier, Biosecurity Interventions: Global Health and Security in Question (New York: Columbia University Press, 2008).

Landecker, H., 'Antibiotic Resistance and the Biology of History', Body \& Society, 22 (2016), 19-52.

Latour, B., The Pasteurization of France (Cambridge, MA: Harvard University Press, 1993).

Law, J., and A. Mol, 'Globalisation in Practice: On the Politics of Boiling Pigswill', Geoforum, 39 (2008), 133-43.

Lorimer, J., 'Probiotic Environmentalities: Rewilding with Wolves and Worms', Theory, Culture \& Society, 34 (2017), 27-48.

The Probiotic Planet: Using Life to Manage Life (Minneapolis: University of Minnesota Press, 2020).

Lorimer, J., and others, 'Making the Microbiome Public: Participatory Experiments with DNA Sequencing in Domestic Kitchens', Transactions of the Institute of British Geographers, 44.3 (2019), 524-41.

Lynteris, C., and B. Poleykett, 'The Anthropology of Epidemic Control: Technologies and Materialities', Medical Anthropology, 37 (2018), 433-41.

Martin, E., 'Toward an Anthropology of Immunology: The Body as Nation State', Medical Anthropology Quarterly, 4 (1990), 410-26.

Mbembe, A., Necropolitics (Durham, NC: Duke University Press, 2019).

Méthot, P.-O., and S. Alizon, 'What Is a Pathogen? Toward a Process View of Host-Parasite Interactions', Virulence, 5 (2014), 775-85.

Mol, A., The Body Multiple: Ontology in Medical Practice (Durham, NC: Duke University Press, 2002).

Nading, A., 'Orientation and Crafted Bureaucracy: Finding Dignity in Nicaraguan Food Safety', American Anthropologist, 119 (2017), 478-90.

Paxson, H., 'Post-Pasteurian Cultures: The Microbiopolitics of Raw-Milk Cheese in the United States', Cultural Anthropology, 23 (2008), 15-47. 
The Life of Cheese: Crafting Food and Value in America. (Berkeley: University of California Press, 2012).

Paxson, H., and S. Helmreich, 'The Perils and Promises of Microbial Abundance: Novel Natures and Model Ecosystems, from Artisanal Cheese to Alien Seas', Social Studies of Science, 44 (2014), 165-93.

Pink, S., Situating Everyday Life: Practices and Places (London and Thousand Oaks: Sage Publications, 2012).

Povinelli, E., Geontologies: A Requiem to Late Liberalism (Durham, NC: Duke University Press, 2016).

Pradeu, T., 'Qu'est-Ce Qu'un Individu Biologique?' in P. Ludwig, and T. Pradeu, eds, L'individu: Perspective contemporaire (Paris: Vrin, 2008), pp. 97-125.

Prainsack, B., and A. Wahlberg, 'Situated Bio-Regulation: Ethnographic Sensibility at the Interface of STS, Policy Studies and the Social Studies of Medicine', BioSocieties, 8 (2013), 336-59.

Rees, T., 'From The Anthropocene To The Microbiocene', Noema (2020) <https:// www.noemamag.com/from-the-anthropocene-to-the-microbiocene/> [accessed 12 December 2020].

Sanford, S., J. Polzer, and P. McDonough, 'Preparedness as a Technology of (in)security: Pandemic Influenza Planning and the Global Biopolitics of Emerging Infectious Disease', Social Theory \& Health, 14 (2016), 18-43.

Sariola, S., and S. Gilbert, 'Toward a Symbiotic Perspective on Public Health: Recognizing the Ambivalence of Microbes in the Anthropocene', Microorganisms, 8.5 (2020), 746.

Sedgwick, E. K., Touching Feeling: Affect, Pedagogy, Performativity (Durham, NC: Duke University Press, 2003).

Shapin, S., and S. Schaffer, Leviathan and the Air Pump (Princeton: Princeton University Press, 1985).

Sharpe, C., In the Wake: On Blackness and Being (Durham, NC: Duke University Press, 2016).

Stengers, I., 'Introductory Notes on an Ecology of Practices', Cultural Studies Review, 11.1 (2005), 183-96.

Strathern, M., 'No Nature, No Culture: The Hagen Case', in C. MacCormack, and M. Strathern, eds, Nature, Culture and Gender (Cambridge: Cambridge University Press, 1980), pp. 174-222.

Tsing, A. L., The Mushroom at the End of the World: On the Possibility of Life in Capitalist Ruins (Princeton: Princeton University Press, 2017).

Vannini, P., Non-Representational Methodologies: Re-Envisioning Research (New York and London: Routledge, 2015).

Wald, P., Contagious: Cultures, Carriers, and the Outbreak Narrative (Durham, NC: Duke University Press, 2008).

Weheliye, A., Habeas Viscus: Racializing Assemblages, Biopolitics, and Black Feminist Theories of the Human (Durham, NC: Duke University Press, 2014). 
WITH MICROBES

Winickoff, D., and D. Bushey, 'Science and Power in Global Food Regulation: The Rise of the Codex Alimentarius', Science, Technology \& Human Values, 35 (2010), 356-81.

Wolf, M., 'Knowing Pandemics', Science \& Technology Studies, 30.4 (2017), 8-29. 